\title{
Термическая стойкость волоконных световодов в специальных покрытиях
}

\author{
С.Л. Семенов ${ }^{*}$, А.Ф. Косолапов \\ Институт общей физики им. А.М. Прохорова РАН \\ Научный центр волоконной оптики им. Е.М. Дианова \\ *E-mail: sls@fo.gpi.ru
}

DOI: $10.31868 /$ RFL2020.138

Стойкость волоконных световодов к высоким температурам определяется в первую очередь свойствами защитного покрытия, которое предохраняет поверхность стеклянного волокна от механических повреждений и прямых контактов с окружающей средой. Также в настоящее время весьма востребованными являются волоконные световоды, одновременно стойкие и к воздействию водорода. Так, например, в нефтегазовой промышленности широко используются волоконно-оптические устройства, эксплуатируемые в водородосодержащей среде при высоких температурах. На сегодняшний день разработаны и успешно применяются различные виды полимерных покрытий, позволяющие использовать волоконные световоды до температуры $300^{\circ} \mathrm{C}$. Для световодов эксплуатируемых при более высоких температурах, используются металлические покрытия. Наибольшее распространение получили алюминиевое и медное покрытия, причем оба этих металла можно наносить как непосредственно на стеклянную поверхность световода, так и поверх подслоя пироуглерода. Световоды в алюминиевом покрытии позиционируются как работоспособные до температур $450^{\circ} \mathrm{C}$, в то время как в качестве максимальной эксплуатационной температуры для покрытых медью световодов указывается $700^{\circ} \mathrm{C}$. При этом практически нет достоверной систематической информации о деградации волокна в условиях повышенных температур и в условиях присутствия водорода.

В докладе будет представлена информация о разработках НЦВО РАН в области специальных волоконных световодов, обладающих, повышенной устойчивостью к температуре, в том числе, в присутствии водорода в окружающей среде. Будет представлена информация о возможностях и ограничениях их использования в подобных условиях.

Исследование выполнено при финансовой поддержке РФФИ № 18-29-17035 